\title{
Na granicy kultur i światów
}

\section{Exploring the border of worlds and cultures}

\author{
Piotr Braszak, Na rozstajnych drogach, około pótnocy. Doświadczenia \\ graniczne we wschodniosłowiańskich i polskich pieśniach ludowych, \\ Wydawnictwo Naukowe UAM, Poznań 2021.
}

DOI: $10.12775 /$ LL.3.2021.0013 | CC BY-ND 4.0

Już sam tytuł książki Piotra Braszaka zapowiada wejście w świat ludowej wyobraźni, która poszukuje odpowiedzi na pytania o granice ludzkiego poznania. Pytania o granice między życiem a śmiercią, między doczesnością a wiecznością nurtują ludzkość od początku dziejów i leżą u podstaw religii. Światopogląd religijny wykracza poza bezpośrednie doświadczenie, przyjmuje istnienie światów równoległych, sił nadprzyrodzonych, kreując mit, który nie tylko pozwala zrozumieć skomplikowaną rzeczywistość i dostarcza wzorców postępowania, ale zaspokaja też potrzebę realizacji marzeń i pokonywania barier strachu w poznawaniu nieznanego. Badacze mitu i religioznawcy (Eliade 20oo: 477; Campbell 1994: 49; Lurker 1994: 9; Szyjewski 2016: 73) przywiązują szczególną uwage do obrazowości narracji mitycznych, które swoją opowieść o początkach budują za pomocą elementów świata materialnego (np. kamienia, wody, drzewa), nadając im znaczenia symboliczne, przez co wchodzą w świat duchowy. Mit jako archetypowe doświadczenie sacrum odznacza się niebywałą trwałością, przybierając coraz to nową postać w obrazach symbolicznych i czynnościach rytualnych, które przez swą powtarzalność nadają mu nowe życie. Symbole stanowią 
więc narracyjne wzorce dla wyobrażeń na temat przenikania się świata z zaświatami, a dla autora omawianej publikacji zarazem klucz do interpretacji pieśni z pogranicza polsko-ukraińsko-białoruskiego, w których zawiera się mikroświat zachowań ludzkich, powielających - w sposób nieuświadomiony - mityczne wzorce.

Książka $\mathrm{Na}$ rozstajnych drogach... stawia sobie za cel rekonstrukcję tradycyjnego sposobu postrzegania i obrazowania relacji między światem żywych i umarłych. Podstawą tej rekonstrukcji są zanikające gatunki folkloru - pieśni rytualne związane z granicznymi momentami życia człowieka, począwszy od narodzin, poprzez zaślubiny, aż do śmierci. Tajemnice przenikania się rzeczywistości ziemskiej z nadprzyrodzoną Braszak ujmuje z dwóch perspektyw - doświadczenia zmysłowego przekraczania granicy światów oraz sposobu postrzegania i wyrażania tych doświadczeń na styku kultur. Obszar graniczny stwarza sprzyjające warunki do porównania analogicznych wyobrażeń utrwalonych w pieśniach polskich, ukraińskich i białoruskich oraz prześledzenia motywów wędrownych i ich zasięgów, zwłaszcza że w tym przypadku mamy też do czynienia z konfrontacją dwóch religii - prawosławia i katolicyzmu. Warunkiem niezbędnym do dokonania rzetelnych badań komparatystycznych jest jednak przedstawienie paralelnego materiału. W omawianej książce większość przytoczonych przykładów pochodzi zza wschodniej granicy. Uwaga autora skupiła się głównie na prezentacji pieśni ukraińskich i białoruskich, gdyż stanowią one w dużej mierze nie publikowany dotąd materiał, podczas gdy dokumentację pieśniową z Lubelszczyzny (a więc trzeciego z badanych obszarów przygranicznych) zaczerpnął z opracowania Polska pieśn i muzyka ludowa. Źródła i materiaty (Bartmiński 2011). Nie umniejszając w niczym wartości zebranych i przetłumaczonych przez Braszaka materiałów (szkoda jednak, że przekład zamieszczono na końcu książki), ich prezentacja w zestawieniu z polskimi odpowiednikami znacznie podniosłaby wartość publikacji, w wielu wypadkach mogłaby bowiem pokazać zupełnie inną ich wymowę. Przykładem może być znana po obu stronach granicy „Pieśń o dzieciobójczyni”. W wersji białoruskiej jej bohaterka w trakcie spowiedzi wykazuje cechy opętania i demoluje kościół, w wersji ukraińskiej niszczy ołtarz, ale wyznanie win przywraca porządek rzeczy, natomiast polski wariant przynosi odmienną wymowę. Tu ciężar zbrodni wielokrotnego dzieciobójstwa powoduje samoistne odwrócenie się ołtarza, trzęsienie ziemi, gaśnięcie świec, a w końcu spopielenie ciała dziewczyny; jej dusza jednak, zgodnie z obietnicą Jezusa, poprzez akt wyznania win zostaje uwolniona od grzechu i zbawiona, a światu przywrócona jest równowaga: ołtarz wraca na miejsce, a świece same się zapalają.

Przyjęcie konceptu granicy jako osi kompozycyjnej książki pozwoliło autorowi na ukazanie wyobrażeń na temat stref liminalnych pomiędzy znanym a nieznanym oraz sposobów ich przekraczania. Wyobrażenia te odnoszą się do czterech żywiołów, które w obrazowaniu wędrówki dusz występować mogą łącznie lub oddzielnie. Najbardziej wyraziste okazały się żywioły wody i ognia. Wydzielenie granic materialnych (czyli dostępnych dla zmysłów wzorku i dotyku, jak miedza, próg domu, wieko trumny, okno, drzwi czy komin) oraz niematerialnych (po- 
strzeganych zmysłem słuchu, np. dźwięk dzwonów podczas uroczystości pogrzebowych) otworzyło perspektywę metafizycznego wymiaru obcowania z zaświatami oraz ich mieszkańcami. Tymi ostatnimi zaś mogą być zarówno bliscy zmarli (np. matka odwiedzająca osierocone dzieci - w pieśniach dziadowskich lub sierocych), jak i osoby boskie oraz święci (np. Jezus, Matka Boska, apostołowie - głównie w kolędach gospodarskich), a także postaci demoniczne (śmierć, diabeł - w balladach). Omówieniu takich postaci zaświatowych w różnych rodzajach pieśni poświęcony jest oddzielny rozdział książki.

Zróżnicowany obraz relacji między tym a tamtym światem uzależniony jest od rodzaju pieśni, które zostały tu sklasyfikowane według przyjętego ogólnie podziału na obrzędowe, rodzinne, powszechne i zawodowe. Rodzaj pieśni można potraktować jako lustro społecznych doświadczeń związanych z sytuacją, $\mathrm{w}$ jakich tekst jest odtwarzany. Zwłaszcza pieśni obrzędowo-rytualne stanowią kanoniczny przykład oralnego sposobu funkcjonowania tekstów folkloru. Ich odbiorcy i nadawcy tworzą bowiem jedność (wspólnotę), a ze względu na powtarzalność sytuacji odtwarzania, tekst pieśni zostaje w sposób naturalny utrwalony w zbiorowej pamięci, stwarzając mocne podstawy dla budowania wzorca i poczucia tożsamości kulturowej. Problematyka pamięci w ostatniej dekadzie stała się tematem zajmującym badaczy różnych dyscyplin; poświęcono jej liczne konferencje i studia (Adamowski, Wójcicka 2012; Czachur 2018), a fundamentalna praca Marty Wójcickiej (2014) pokazał wpływ oralności na funkcjonowanie pamięci zbiorowej. Oralny przekaz leży u podstaw kreacji wariantów tekstowych oraz ich rozpowszechniania w przestrzeni i w czasie, dzięki czemu powielane wzorce i motywy nabierają nowego życia i - jak zauważa Braszak - znajdują „zastosowanie” również we współczesnej kulturze masowej.

Przeprowadzona przez autora analiza pieśniowych motywów służących do kreowania granic i przestrzeni między tym a tamtym światem wykazała, że charakteryzuje je znaczne bogactwo i zróżnicowanie. Świadczy to o tym, że w światopoglądzie ludowym zakładano nieograniczone wręcz możliwości przenikania zaświatów do wszystkich sfer życia ziemskiego. Miejsca graniczne widziano w różnych obszarach, począwszy od ciała człowieka i jego ubrania (stąd np. ochronną funkcje pełniły runiczne obszycia i hafty na zewnętrznych krawędziach koszuli), poprzez przestrzeń mieszkalną (chronioną przez progi, drzwi, okna, ogrodzenia i płoty), aż po bariere między światem żywych a umarłych (np. mur cmentarny). Jak pokazał Braszak, poczucie zagrożenia ze strony zaświatowej rzeczywistości widoczne jest $\mathrm{w}$ analogiach między czynnościami towarzyszącymi różnym rytuałom przejścia związanym z narodzinami, ślubem i śmiercią. Przykładem mogą być symbolika łącząca drewnianą kołyskę z trumną, kołysanki nucone na modłe pieśni żałobnych czy rytualny płacz panny młodej, stanowiący paralele lamentu pogrzebowego. Warto podkreślić, że autor wiąże doświadczenia graniczne nie tyle $\mathrm{z}$ atmosferą grozy, ile $\mathrm{z}$ utrwalonym $\mathrm{w}$ zbiorowej wyobraźni symbolicznym „pejzażem nieznanego”, który wywołuje poczucie obcości, a swymi korzeniami sięga mitu. Śpiew obrzędowy miał tę obcość oswoić, przybliżyć, uczynić zrozumiałą, a także chronić uczestników obrzędu przed ingerencją złych mocy. 
Rytualny śpiew przywołuje niematerialne granice między znanym a nieznanym wyznaczane poprzez głos w opozycji do ciszy i milczenia. Wyrazistym przykładem obrzędu, w którym współwystępują naprzemiennie dźwięk i cisza jest ceremonia pogrzebowa. Doświadczenie śmierci osoby bliskiej należy do najbardziej traumatycznych przeżyć powodowanych wtargnięciem rzeczywistości zaświatowej do świata żywych. Lament pogrzebowy należy do typów ekspresji występujących na terenach Słowiańszczyzny wschodniej i południowej, w Polsce spotykanej jedynie na obszarze pogranicza. Rytualne zwodzenia w formie dialogów ze zmarłym należą do bardzo archaicznych zwyczajów pogrzebowych, sięgających czasów przedchrześcijańskich. Kazimierz Moszyński (1939: 1517) wyszczególnia sześć składników lamentu, wyrażanych poprzez pytania retoryczne kierowane do nieżyjącej osoby: 1) przyczyna odejścia („Dlaczego odszedłeś?”); 2) skarga osieroconych („Jak będziemy teraz żyć?”); 3) prośba, by zmarły ocknął się („Obudź się!, Wróć!”); 4) skarga, że już nigdy się go nie zobaczy i nie usłyszy; 5) gotowość odejścia ze zmarłym („Zabierz mnie ze sobą!”); 6) pożegnalne oddanie hołdu zmarłemu („O mój kochany!”). Krzyk lamentu przerywa ciszę ceremonii pogrzebowej, a opłakiwanie zmarłego w formie śpiewnej recytacji pełni wielorakie funkcje: wyraża bunt wobec zjawiska śmierci i żal po stracie, stanowi rodzaj pomocy udzielanej zmarłemu w przejściu na tamten świat. Ponadto takie publiczne pożegnanie stanowi akt ostatecznego wyłączenia ze świata żywych, a tym samym zabezpieczenie rodziny przed powrotem nieboszczyka. Krzyk rozpaczy to akt jedności ze wspólnotą a zarazem publiczne ogłoszenie śmierci (Kościuk 20211: 66o-663).

W książce Braszaka przedmiotem szczegółowej interpretacji są obecne w pieśniach lirycznych motywy dźwięku dzwonów i organów kościelnych, które oznajmiają śmierć i stanowią głosową reprezentacje granicy zaświatów. Problematyka dźwięków w krajobrazie była już poddawana interdyscyplinarnym badaniom (Bernat 2008; Klima 2008), a funkcję i symbolikę dzwonów szeroko omawiali m.in. Małgorzata Dziura $(2017,2019)$ oraz Robert Losiak, który wskazał na to, że „[d]źwięk dzwonów symbolicznie wytycza granice przestrzeni, stanowi foniczne otoczenie miejsca, wyznacza swoisty »słuchokrąg«, który określa miejsce bezpieczne, oswojone, do którego nie mogą wtargnąć złe moce i żywioły” (Losiak 2011: 46). W konsekwencji obszar pozbawiony odgłosu dzwonów jawi się jako niebezpieczny, nieczysty, przejmujący grozą. Bicie dzwonów w wyznaczonych porach dnia, nadaje życiu rytm, wpisuje się w krajobraz tradycyjnej wsi naznaczony typowymi odgłosami, jak rżenie koni, ryczenie krów, pianie kogutów, brzęk ostrzenia kos. I choć niektóre z tych dźwięków już nie funkcjonują w wiejskiej rzeczywistości, jednak nadal żyją w pamięci mieszkańców i przywoływane są w nostalgicznych wspomnieniach czasów, które minęły. Warto zauważyć, że w magicznych formułach odpędzania choroby śmierć często postrzegana jest właśnie w opozycji do życia wypełnionego typowymi dla niego odgłosami, jako strefa głucha i odległa, gdzie „koń nie doskoczy, ptak nie doleci, kogut nie dopieje”.

Książka Piotra Braszaka wnosi do dotychczasowych badań nad podjętą problematyką perspektywę mikroświata pieśni, usytuowanego na styku kultur, 
w którym kontakt między rzeczywistością ziemską i zaświatową ma fundamentalne znaczenie. Ograniczenie rozważań do jednej formy folkoru pozwoliło autorowi ukazać, jak w obrębie poszczególnych rodzajów pieśni dochodzi do komunikacji między tym a tamtym światem, w jakie sfery życia ziemskiego ingeruje rzeczywistość zaświatowa, jak człowiek się przed nią zabezpiecza i jak oraz w jakich sytuacjach sam próbuje przekraczać jej granice. Analiza materiału pochodzącego z pogranicza pokazała zarazem, że same pieśni również przekraczają granice i choć trudno prześledzić drogi ich wędrówek, to porównanie języka, a zwłaszcza symboliki, znacznie poszerza perspektywe poznawczą, pokazując zawarty w nich system wartości, ocen oraz sposobów obrazowania i wyrażania ekspresji.

\section{BIBLIOGRAFIA}

Adamowski, J., Wójcicka, M. (red.) (2012). Pamięć jako kategoria rzeczywistości kulturowej. Lublin: Wydawnictwo UMCS.

Bartmiński, J. (red.) (2011). Polska pieśń i muzyka ludowa. Źródła i materiały: T. 4. Lubelskie: Cz. 2. Pieśni i obrzędy rodzinne. Lublin: Instytut Sztuki PAN, UMCS, Polihymnia.

Bernat, S. (red.) (2008). Dźwięk w krajobrazie jako przedmiot badań interdyscyplinarnych. Lublin: Instytut Nauk o Ziemi UMCS, Komisja Krajobrazu Kulturowego PTG.

Campbell, J. (1994). Potęga Mitu. Rozmowy Billa Moyersa z Josephem Campbellem (przeł. I. Kania). Kraków: Znak.

Cirlot, J. E. (2001). Stownik symboli (przeł. I. Kania). Kraków: Znak.

Czachur, W. (red.) (2018). Pamięć w ujęciu lingwistycznym. Zagadnienia teoretyczne i metodyczne. Warszawa: Wydawnictwa Uniwersytetu Warszawskiego.

Dziura, M. (2017). Dzwon w pejzażu pogranicza nadsańskiego. Przemyśl: Muzeum Narodowe Ziemi Przemyskiej.

Dziura, M. (2019). Rola i znaczenie dźwięku dzwonów w kształtowaniu poczucia zadomowienia. Journal of Urban Ethnology, 17, 259-278, doi: https://doi.org/10.23858/JUE17.2019.016

Eliade, M. (200o). Traktat o historii religii (przel. J. Wierusz-Kowalski). Warszawa: Wydawnictwo KR.

Klima, E. (2008). Dźwięki i cisza jako składowe przestrzeni sacrum. W: S. Biernat (red.), Dźwięk w krajobrazie jako przedmiot badań interdyscyplinarnych (s. 173-181). Lublin: Instytut Nauk o Ziemi UMCS, Komisja Krajobrazu Kulturowego PTG.

Kościuk, A. (2011). Lamenty pogrzebowe. W: J. Bartmiński (red.), Polska pieśń i muzyka ludowa. Źródła i materiały. T. 4. Lubelskie. Cz. 2. Pieśni i obrzędy rodzinne (s. 66o-663). Lublin: Instytut Sztuki PAN, UMCS, Polihymnia.

Losiak, R. (2011). Recepcja dźwięków świątyń we współczesnym krajobrazie fonicznym miast. W: S. Bernat (red.), Niematerialne wartości krajobrazów kulturowych (s. 38-53). Sosnowiec: Komisja Krajobrazu Kulturowego PTG.

Lurker, M. (1994). Przestanie symboli w mitach, kulturach i religiach (przeł. R. Wojnakowski). Kraków: Znak.

Moszyński, K. (1939). Kultura ludowa Stowian: Cz. 2. Kultura duchowa (z. 2). Kraków: Polska Akademia Umiejętności.

Szyjewski, A. (2016). Etnologia religii. Kraków: Nomos.

Wójcicka, M. (2014). Pamięć zbiorowa a tekst ustny. Lublin: Wydawnictwo UMCS. 